\title{
Late Cretaceous Amber in Texas: Chemical Characterization and Paleoenvironment ${ }^{1}$
}

\author{
Virginia Friedman ${ }^{2}$, Joseph B. Lambert ${ }^{3}$, Tayde A. Contreras ${ }^{2}$, \\ Edith Stout ${ }^{4}$, Sarjit Kaur ${ }^{4}$, and Hanna Mitamura ${ }^{4}$
}

\begin{abstract}
Amber is reported from a new locality in North Central Texas, USA. The amber clasts were found in thin carbonaceous horizons in the Woodbine Group. They exhibit a variety of colors including yellow, orange, red, brown and opaque white. No zooinclusions have been found, but some clasts present plant debris and inorganic inclusions. ${ }^{13} \mathrm{C}$ NMR, ${ }^{1} \mathrm{H}$ NMR, FTIR, and GC/MS analyses assign this amber to Group A or Class $1 \mathrm{~b}$ and, as such, the botanical origin is considered to be a conifer. The low diversity palynomorph assemblage of the sediments is suggestive of a nearby source. The paleoenvironment is interpreted as non-marine, fluvial deltaic. Abundant charcoal fragments are noted. This observation is in concordance with the description of the Cretaceous period being a time of fires. Based on stratigraphic and palynologic data, the age of the amber is Early Cenomanian. This research represents the first study of amber in Texas.
\end{abstract}

Key Words: amber, Cretaceous, NMR, FTIR, GC-MS, Woodbine, North Central Texas.

The term amber refers to a plant resin of gymnosperm or angiosperm botanical affinity that, through millions of years of aging, or maturation, has undergone physicochemical modifications through diagenetic processes in the matrix in which it first was deposited. Most of the amber in the world is secondarily deposited, meaning that the sediments already deposited are eroded and redeposited. Amber is rarely found in primary deposits. There are many amber deposits in the world, in many geographical settings, and from many geological ages, but most lack economic importance. Some of the deposits are well documented, while others are just mentioned casually in obscure literature. To amber researchers (resin chemists, paleontologists, sedimentologists, paleoentomologists, paleobotanists, and others), all are scientifically important, because all these resins offer new opportunities for research in a wide variety of

\footnotetext{
${ }^{1}$ Received on January 31, 2018. Accepted on February 11, 2018. Last revisions received on February 26, 2018.

21000 Walnut Place, Mansfield, Texas 76063 USA. E-mail: friedmanhvj@aol.com

3 Trinity University, Department of Chemistry, San Antonio, Texas 78212 USA. E-mails: jlambert@trinity.edu and tcontrer@trinity.edu, respectively.

${ }_{4}$ Amber Research Laboratory, Chemistry Department, Vassar College, Poughkeepsie, New York 12604 USA. E-mails: sakaur@vassar.edu, stout@vassar.edu, and hamitamura@vassar.edu , respectively.
}

DOI: 10.9784/LEB5(3)Friedman.01

Electronically available on February 26, 2018. Mailed on February 26, 2018. 
disciplines. As new analytical tools become available, more and more research into these fossilized resins is warranted.

Such fossil resins have caught the attention of mankind since Neolithic times (Langenheim 2003). Most likely, early humans found pieces of this extraordinary material entangled among seaweeds and float debris while walking alongside the shores of the North and Baltic seas after a storm late in the year (Reinicke 1990). It may have been the warmth of a piece of amber to the touch, the different hues it presents, or the biological inclusions it sometimes contains that made it quite attractive to them and inspired these early people to imbue amber with mythical qualities. Perhaps its association with the color of the sun in the blue sky inspired the fabulous so-called solar amulets dating back to the Stone Age, which have been found as archaeological artefacts in many sites along the shores of the Baltic and North Seas (Grabowska 1983). Indeed, amber has been known to many cultures around the world from the New Stone Age (Neolithic Period), Bronze Age, and Iron Age. Cultures that have worked with or traded amber include the ancient Balts, Etruscans, Phoenicians, Romans, Greeks, and others (Langenheim 2003). In the New World, amber was known before the arrival of Columbus by the ancient civilizations of the Aztecs and Mayas in Mesoamerica. Today, amber is still very much in vogue mainly in jewelry, also as raw material for modern sculptures, as well as in many diverse accessories made of amber. Simply stated, amber is timeless, and its chemical stability is remarkable (Friedman et al. 2017).

Here, we present our current research on the chemical characterization and environment of deposition of a new amber-bearing locality (Upper Cretaceous, Cenomanian) in Grayson County, North Central Texas (Friedman et al. 2017). The data generated by the analytical techniques applied to the Texas amber are ${ }^{13} \mathrm{C}$ and ${ }^{1} \mathrm{H}$ NMR spectroscopy, FTIR and GC/MS lead to the chemical characterization of this amber.

\section{Geological Setting}

The amber in Texas has been found stratigraphically in the Woodbine Group in Grayson County, North Central Texas, exact location on file (Fig.1). The Woodbine, then, Formation, named by Hill (1901) for a town in Cooke County, Texas, is the basal formation of the Gulf Series of the Upper Cretaceous in North America. The Woodbine is the source rock of the East Texas oil field, one of the largest oil fields on the North American continent. The Woodbine overlies the Grayson Marl, uppermost member of the Washita Group, and it is unconformably overlain by the Eagle Ford Group. The Woodbine crops out in a narrow irregular band up to $32 \mathrm{Km}$ wide in Texas, Oklahoma, and Arkansas. Three principal depositional systems are recognized in the regressive Woodbine Group: a fluvial system, a high-destructive delta system and a shelf-strand plain system (Oliver 1971). In outcrop the Woodbine consists of brown to tan, fine to coarse-grained, conglomeratic, ferruginous, moderately to weakly indurated, 
cross-bedded sandstones with interbedded gray shale and lignite with a total thickness of about 133 m (Wilkins 1988).

Four members were recognized within the Woodbine Formation by Dodge (1952), in ascending order: Rush Creek, Dexter, Lewisville, and Arlington. The amber-bearing locality of this study was found at the stratigraphic level of the non-marine Dexter Member (Figure 2). The amber clasts were found irregularly distributed within a narrow (not more than $15 \mathrm{~cm}$ in thickness) carbonaceous matrix of finely disaggregated charred wood (fusain) and centimeter length charcoal fragments. Amber is also found, although not commonly, in the above siltstones and mudstones beds (Figure 3). The lateral extent of the amberbearing beds is about $10 \mathrm{~m}$ but is discontinuous in nature. The amber clasts vary in size from $1 \mathrm{~mm}$ in diameter to about $3 \mathrm{~cm}$. The Dexter Member consists of a maximum of 40 to $47 \mathrm{~m}$ of irregularly bedded non-calcareous sands, sandstones, and interbedded clays and shales. These sediments are believed to have been deposited on the flood plains of streams flowing seaward across a coastal plain during the early Late Cretaceous and in fresh-water lakes and lagoons on the coastal plains (Stephenson 1952).

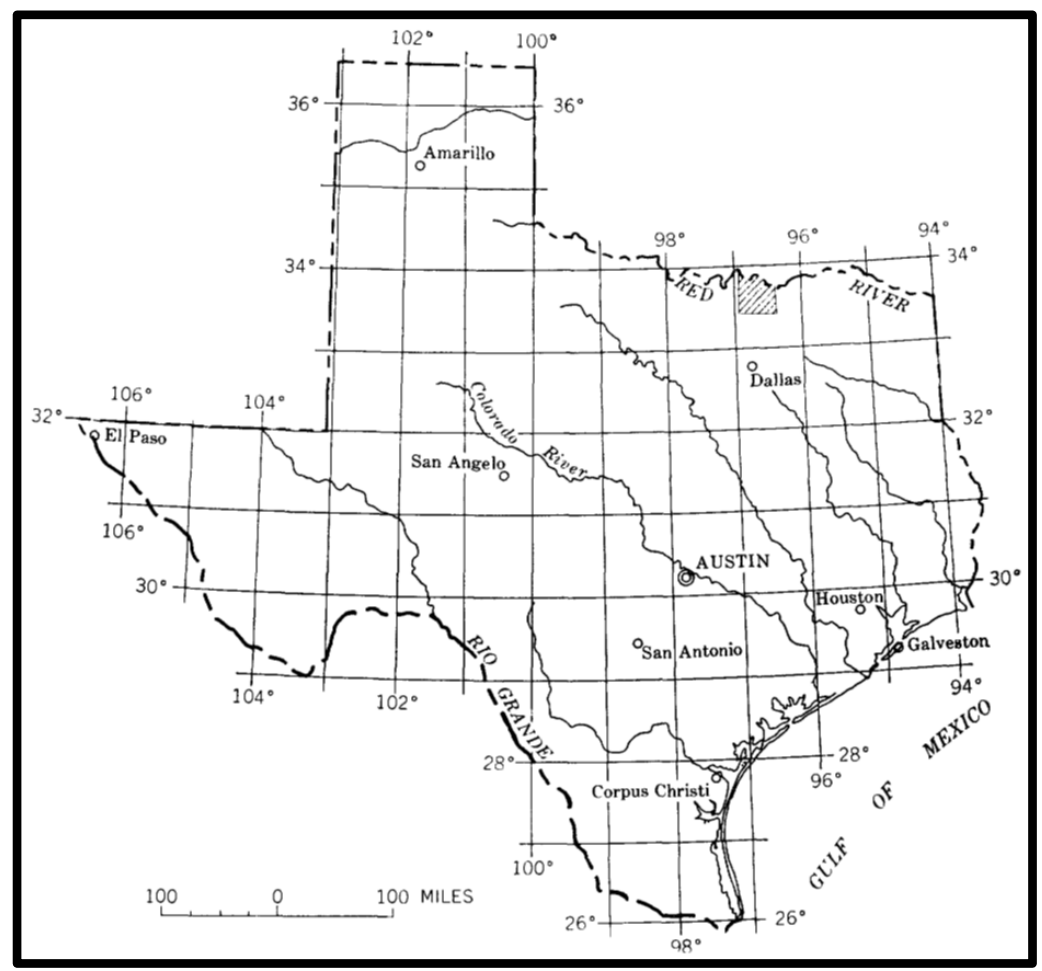

Figure 1. Map of Texas showing location of Grayson County (shaded area). 


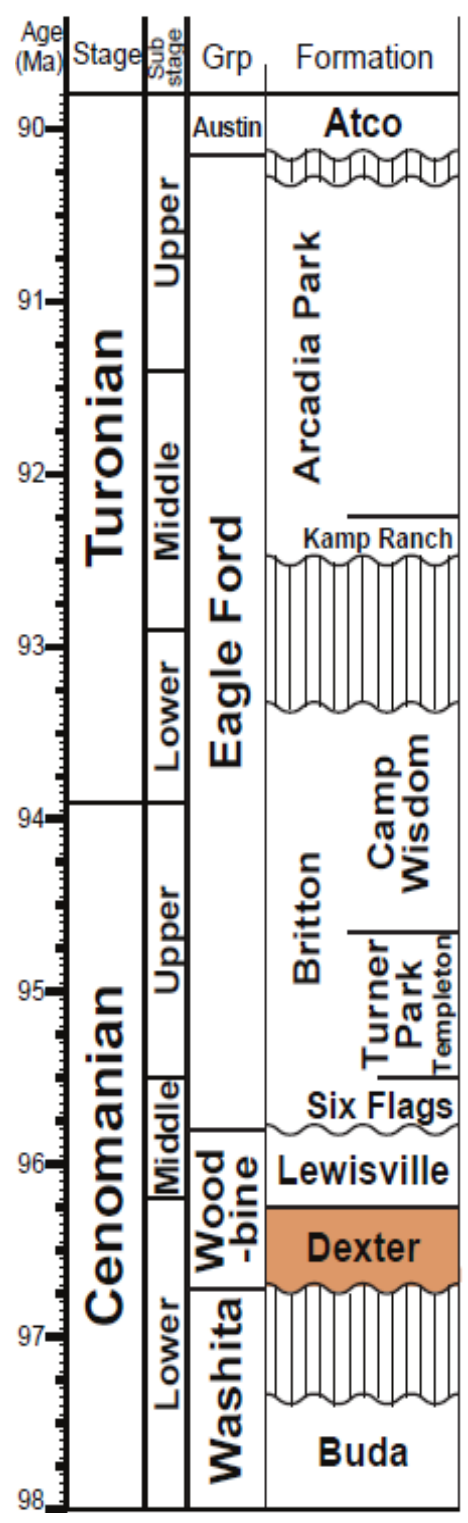

\section{Methods}

Ten bags of sediment weighing approximately $1 \mathrm{~kg}$ each were collected from the carbonaceous horizon at the locality. These samples were soaked in tap water for $48 \mathrm{~h}$ to disaggregate the sediments and later passed through a 63-micron sieve to recover the smallest clasts of amber. Once recovered by hand, they were left to dry at room temperature for several days. The clasts were divided into fractions according to size: small (sand size pieces aproximately $1 \mathrm{~mm}$ in diameter), medium (2-9 $\mathrm{mm})$, and large $(10-30 \mathrm{~mm})$, and according to color. Some amber clasts are transparent, others are translucent, while others are completely opaque. The hues present are pale yellow, yellow, dark yellow, orange, reddish, and dark brown opaque (Figures. 4, 5, and 6). Some clasts are bony white, and others exhibit a combination of colors. Some present an outer rough crust that gives them the appearance in the field of a hickory nut. The larger clasts were set aside in Riker mounts for reference. The examination under a stereoscope (x40 magnification) in search of organic and inorganic inclusions is ongoing. No definitive zooinclusions have been found yet. Many amber clasts present phytoinclusions, but they appear for the most part detrital and not suitable for taxonomical classification.

Figure 2. Chronostratigraphic column showing stratigraphic position of Dexter member of the Woodbine Group in North central Texas (modified after Denne 2016). 


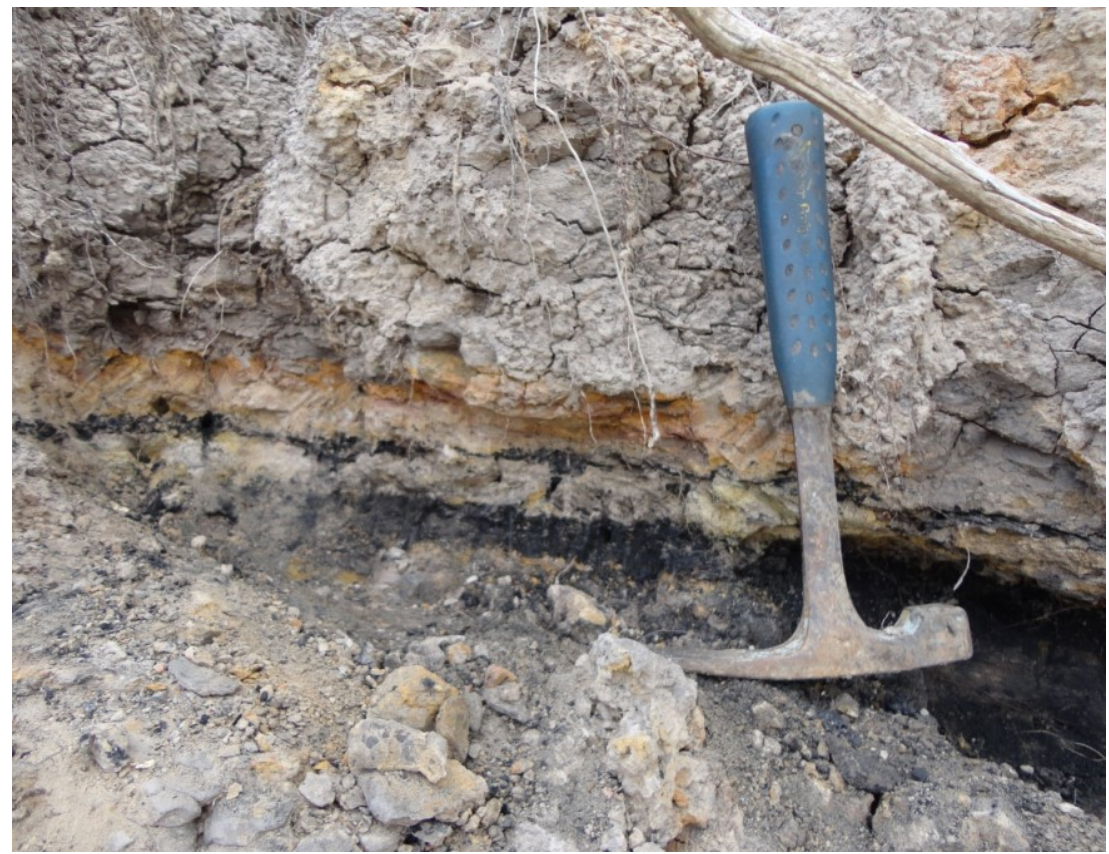

Figure 3. Carbonaceous beds where amber clasts were found.

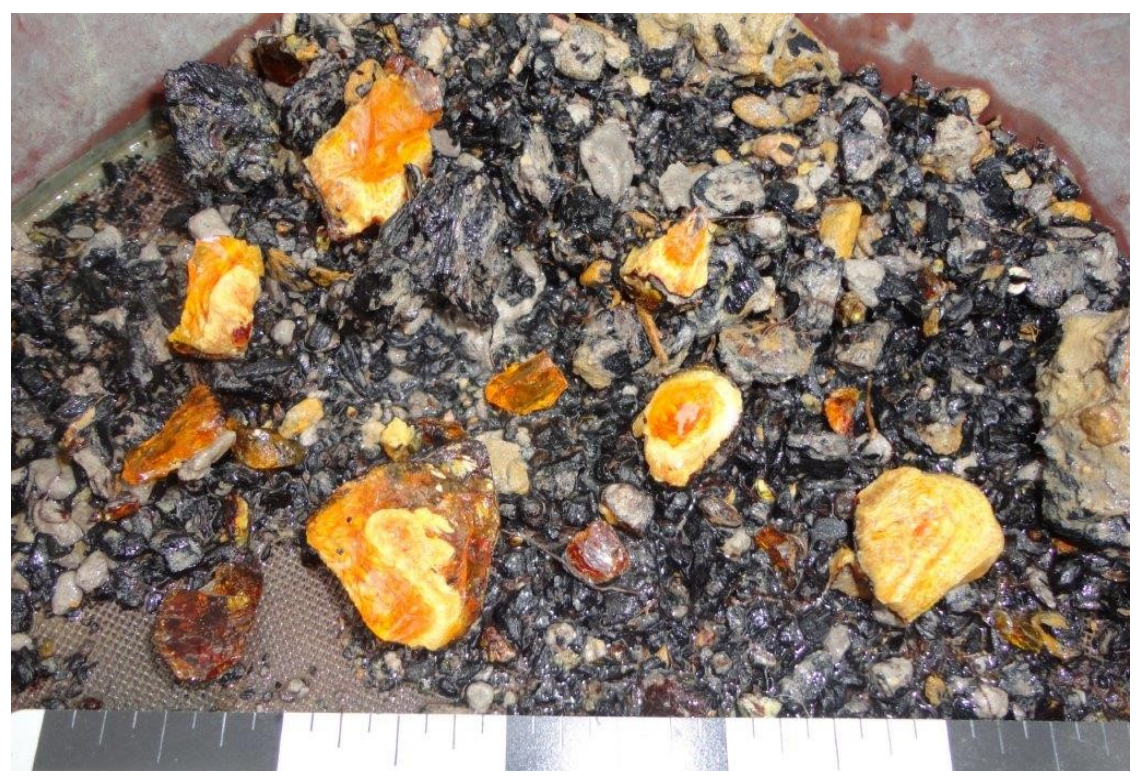

Figure 4. Amber clasts found at the locality. 


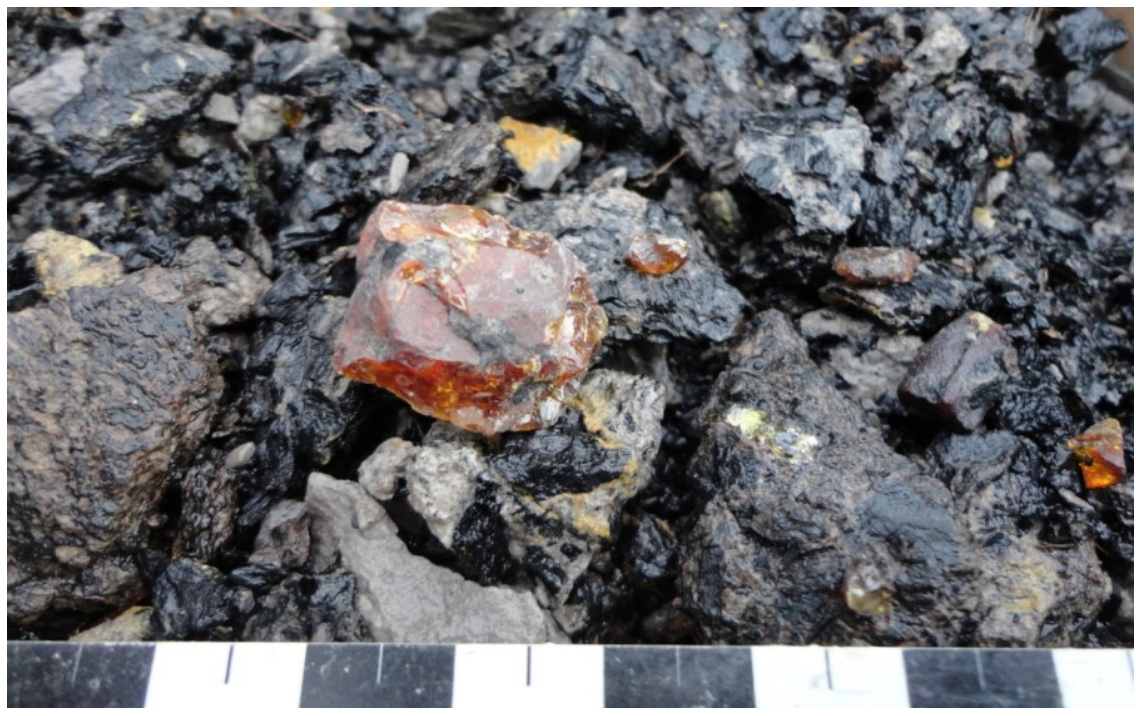

Figure 5. Red amber clast against a background of charred wood.
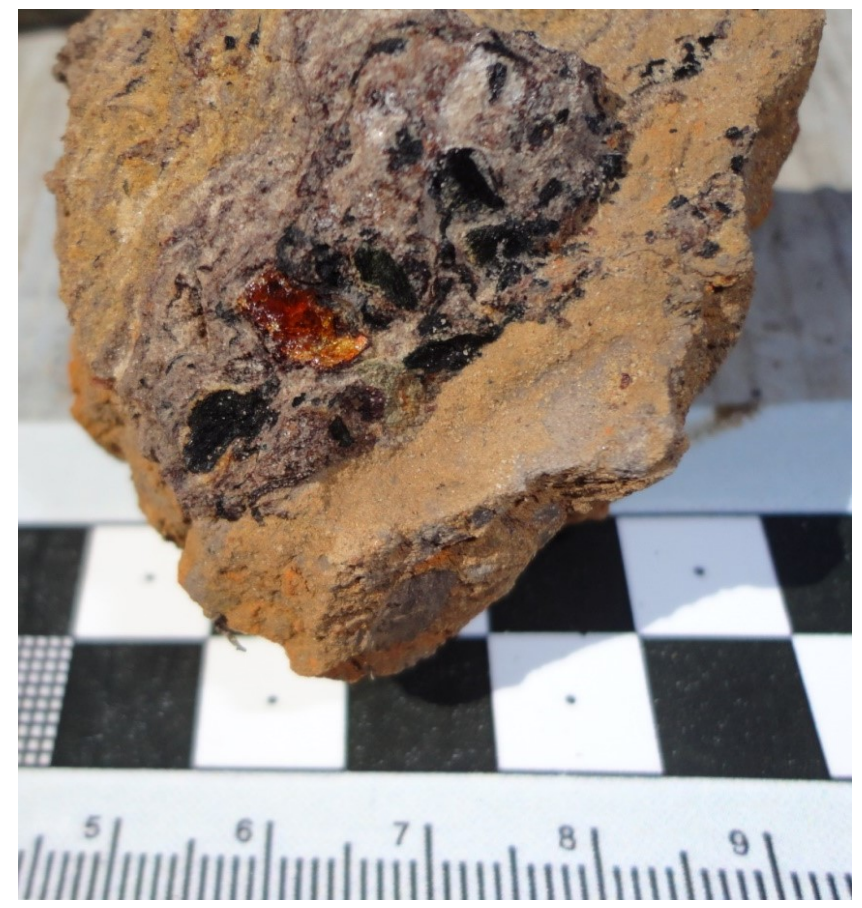

Figure 6. Amber clast in lignitic clay and outer sandstone matrix. 
Inorganic inclusions are abundant: microscopic bubbles of different size and shape (Figure 7), bubbles inside bubbles, and acicular (needle-like) sulfate crystals (probably jarosite or selenite) have been observed. Samples of sediment in which the amber clasts were found were analyzed to determine their palynomorph and kerogen content following standard techniques. For the chemical characterization of this fossil resin, specimens were studied by the following analytical techniques: Solid-state ${ }^{13} \mathrm{C}$ and solution ${ }^{1} \mathrm{H}$ nuclear magnetic resonance (NMR) spectroscopy, Fourier Transform infrared (FTIR) spectroscopy, and gas chromatography/mass spectrometry (GC/MS).

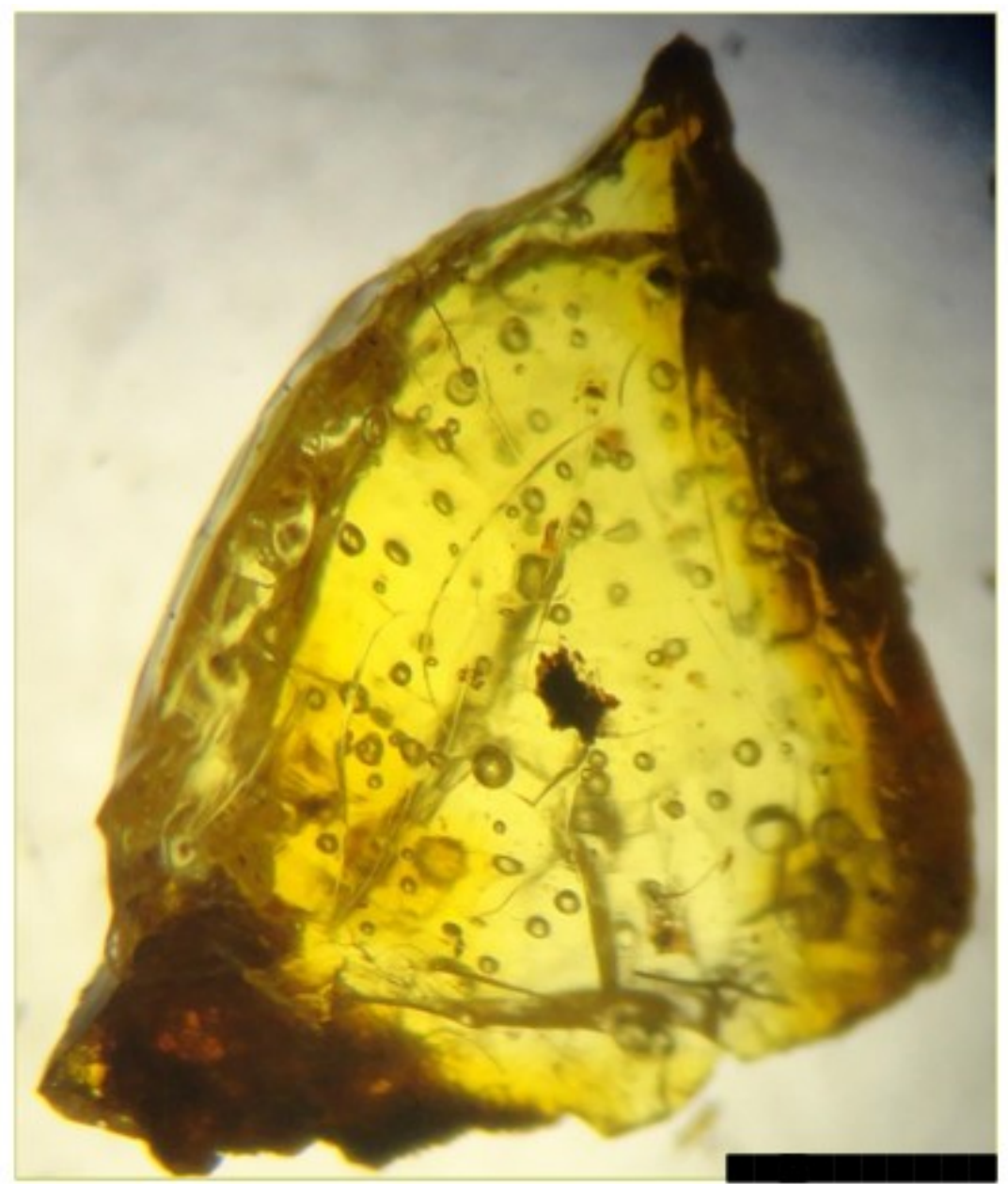

Figure 7. Inorganic inclusions: Bubbles. Scale bar $=1 \mathrm{~mm}$. 
Each sample was subjected to four different NMR experiments. (1) Observation of ${ }^{13} \mathrm{C}$ nuclei of powdered, solid samples with full decoupling of carbon from hydrogen, that is, removal of the scalar coupling interactions between these nuclei (Lambert et al. 2008). By examination of the bulk, this analysis is assured to characterize the entire sample. (2) Observation of ${ }^{13} \mathrm{C}$ nuclei of solid state samples with partial decoupling of carbon from hydrogen, using the technique known as dipolar dephasing or interrupted decoupling (Opella and Frey 1979). This experiment selects largely for carbon nuclei that are not attached to a hydrogen atom and provides an alternative method to distinguish spectral classes. (3) Standard one-dimensional (1D) observation of ${ }^{1} \mathrm{H}$ nuclei in solution state, usually with deuterated chloroform $\left(\mathrm{CDCl}_{3}\right)$ as the solvent. Examination of the solution phase may involve some loss of material due to partial insolubility. (4) The two-dimensional (2D) ${ }^{1} \mathrm{H}$ method known as COSY (COrrelation SpectroscopY), in which both Cartesian coordinates represent the frequency of ${ }^{1} \mathrm{H}$ resonances. Proton NMR spectra can provide distinctions sometimes not apparent from ${ }^{13} \mathrm{C}$ spectra (Lambert et al. 2012).

For ${ }^{13} \mathrm{C}$ NMR measurements (taken at $100 \mathrm{MHz}$ ), samples were ground into a fine powder and loaded into a Varian $5 \mathrm{~mm}$ general purpose Zirconia rotor sealed with Vespel caps. The optimal sample load is about $150 \mathrm{mg}$ of material, but smaller sample sizes (as little as $50 \mathrm{mg}$ ) required larger scan numbers. Spectra were recorded at Northwestern University. For ${ }^{1} \mathrm{H}$ spectra (taken at 500 $\mathrm{MHz}$ ), approximately $55 \mathrm{mg}$ of powdered exudate (recovered from ${ }^{13} \mathrm{C}$ analysis) was transferred to a small, glass vial. About $1 \mathrm{~mL}$ of deuterated chloroform-d was added to each vial. The material was stirred at room temperature and allowed to sit overnight. The supernatant was pipetted out and transferred to the NMR tube. Spectra were recorded at Trinity University. The solutions were evaporated to retrieve the sample, and all powders have been retained, along with unused materials, in the archive at Trinity University (San Antonio, Texas).

FTIR spectroscopy was carried out with $\mathrm{KBr}$ pellets and, on pure solid samples, by attenuated total reflectance (ATR). Pellets were made by grinding 1 $\mathrm{mg}$ of the sample and $250 \mathrm{mg} \mathrm{KBr}$ into a fine powder, which was pressed into a pellet under high pressure and vacuum. Identical FTIR spectra were obtained by both methods. The larger sample also was analyzed by gas chromatograph-mass spectrometry (GC/MS). The sample was treated with an organic solvent of dichloromethane and ether $(50 / 50 \mathrm{v} / \mathrm{v})$ and methylated with diazomethane to convert carboxylic acids to methyl esters to enhance analysis by GC/MS.

The infrared spectra were obtained with a ThermoNicolet FTIR Nexus 670 model, and GC/MS analysis was carried on the methylated organic extract with an Agilent Technologies 7890AGC/5975 GC/MS model fitted with a Hewlett Packard poly(methylsiloxane) capillary column (HP-1 ms, $15 \mathrm{~m} \times 0.25 \mathrm{~mm}$ ) using the following parameters: injection port $250^{\circ} \mathrm{C}$, electron impact at $70 \mathrm{eV}$, and column heated from $50-250{ }^{\circ} \mathrm{C}$ at $5{ }^{\circ} \mathrm{C} / \mathrm{min}$, and held for $20 \mathrm{~min}$. 


\section{Results}

Palynology and Paleoenvironment of the Locality

Palynological recovery at the outcrop where 19 palynomorph taxa were observed, as follows.

Table 1. Taxa observed in amberiferous sediments from Grayson County, Texas, USA. Taxa are arranged by decreasing order of abundance, then taxonomically, and alphabetically, in that order.

\begin{tabular}{|c|c|c|}
\hline$\%$ & Taxon Authorship (organism group) & Event Age \\
\hline 26 & Deltoidospora hallii Miner, 1935 (fern spore) & \\
\hline 20 & Pinuspollenites spp. (gymnosperm, conifer pollen) & \\
\hline 10 & $\begin{array}{l}\text { Biretisporites potoniaei Delcourt and Sprumont, } 1955 \\
\text { (fern spore) }\end{array}$ & \\
\hline 7 & Granulatisporites spp. (fern spore) & \\
\hline 6 & Todisporites minor Couper, 1953 (fern spore) & \\
\hline 6 & Parvisaccites spp. (gymnosperm, conifer pollen) & \\
\hline 4 & $\begin{array}{l}\text { Taxodiaceaepollenites hiatus (Potonie, 1931) Kremp, } \\
1949 \text { (gymnosperm, conifer pollen) }\end{array}$ & \\
\hline 3 & $\begin{array}{l}\text { Cicatricosisporites hallei Delcourt and Sprumont, } 1955 \\
\text { (fern spore) }\end{array}$ & \\
\hline 3 & $\begin{array}{l}\text { Pinuspollenites labdacus (gymnosperm, conifer pollen) } \\
\text { (Potonié, 1958) }\end{array}$ & \\
\hline 2 & Kiokansium polypes Below, 1982 (dinoflagellate alga) & LAD Cenomanian \\
\hline 2 & $\begin{array}{l}\text { Lycopodiacidites cerniidites (Ross, 1949) Brenner, } 1963 \\
\text { (fern spore) }\end{array}$ & $\begin{array}{l}\text { LAD Early } \\
\text { Cenomanian }\end{array}$ \\
\hline 2 & Matonisporites equiexinus Couper, 1958 (fern spore) & LAD Cenomanian \\
\hline 2 & $\begin{array}{l}\text { Triplanosporites sinuosus Thomson and Pflug, } 1953 \\
\text { (fern spore) }\end{array}$ & FAD Albian \\
\hline 2 & $\begin{array}{l}\text { Verrucatosporites pseudoreticulatus Pflug and } \\
\text { Thomson, } 1953 \text { (fern spore) }\end{array}$ & $\begin{array}{l}\text { Late Albian to } \\
\text { Middle Cenomanian }\end{array}$ \\
\hline 1 & $\begin{array}{l}\text { Triporoletes cenomanianus Srivastava, } 1977 \text { (bryophyte } \\
\text { spore) }\end{array}$ & $\begin{array}{l}\text { Late Albian to } \\
\text { Middle Cenomanian }\end{array}$ \\
\hline 1 & $\begin{array}{l}\text { Cicatricosisporites australiensis Potonié, } 1956 \text { (fern } \\
\text { spore) }\end{array}$ & \\
\hline 1 & Cicatricosisporites spp. (fern spore) & \\
\hline 1 & Laevigatosporites irroratus Hedlund, 1966 (fern spore) & $\begin{array}{l}\text { Late Albian to } \\
\text { Middle Cenomanian }\end{array}$ \\
\hline 1 & $\begin{array}{l}\text { Tsugaepollenites nexosus Hedlund, } 1966 \text { (gymnosperm, } \\
\text { conifer pollen) }\end{array}$ & Cenomanian \\
\hline
\end{tabular}

$\mathrm{LAD}=$ Last appearance datum. $\mathrm{FAD}=$ First appearance datum. 
The low diversity of the assemblage suggests a relatively local source for the palynomorphs. A greater diversity would be expected if materials were transported from a broader area. Fern spores and conifer pollen dominate the assemblage (Zippi 2016; this study). Fern spores are unlikely to have been transported from outside the local area in large numbers because fern spores are not easily wind-transported (Drehobl 2013). The paleoenvironment was likely a fern swamp within a broader lower delta floodplain. Lower delta plain, and proximity to a marine system, is indicated by the presence of $2 \%$ dinoflagellate specimens. The kerogen composition is characteristic of an ancient fluvial system (kerogen: primarily dark charcoal wood tracheids 59\%, plant cuticle $31 \%$, spores/pollen $7 \%$ and angular resin particles 3\% (Zippi 2016). The palynological data seem to indicate that the biological source of the Texas amber was a conifer, which could have been a member of the Pinaceae due to the high percentage of pine pollen in the host sediments. The meaning or significance of the charred wood present at the horizon in which the amber was found is suggestive of the direct effect of fire at or immediately prior to the time when the deposit was laid down. This scenario appears to be the case in other amber localities in other geographical areas. Conifer wood charcoal is common also in those sediments. According to Scott (2010), the Cretaceous Period was a high fire world.

\section{Age of the Texas Amber}

The Woodbine Group is a Cenomanian age unit of the Late Cretaceous. Its age (90-100 Ma) was established biostratigraphically by Kennedy and Cobban (1990) using ammonites from marine members in the upper part of the Formation. In 2015, Donovan et al. refined the Woodbine as a mid-early Cenomanian to earliest middle Cenomanian chronostratigraphic unit (96 to 97.7 Ma). In their estimation, the deposition of the Dexter Member (lower Woodbine Group), was about 500,000 years in duration. The stratigraphic position of the carbonaceous horizon where the amber clasts were found lies within the Dexter Member. Therefore, an age of Early Cenomanian is assigned to the newly found amber-bearing deposit.

This age assignment is also in accordance with the palynological data gathered from sediments collected at the locality under study (Table 1) (Zippi 2016). These data are suggestive of an age restricted to Late Albian to Early Cenomanian by the first appearance (FAD) of Triplanosporites sinuosus, Verrucatospotites pseudoreticulatus, Triporoletes cenomanianus, and Laevigatosporites irroratus; and the last appearance (LAD) of Lycopodiacidites cerniidites.

The Texas amber is roughly contemporaneous with other important amber deposits in North America such as the Raritan Formation of New Jersey and another on Kreischerville, Staten Island, New York, which also were recognized as middle Cretaceous in age (Cenomanian stage) by Hollick (1905). A similar 
amberiferous outcrop was reported in Cape Sable, Magothy River, Anne Arundel County in Maryland (Troost 1821). Nevertheless, more recent reports assign a Turonian age to the New Jersey deposits (Grimaldi 2000). Towards middle North America, the amber deposit found in Ellsworth County, Kansas was assigned to the Cenomanian (Langenheim et al. 1965). In other geographical areas of the world the Texas amber is contemporaneous with Cenomanian deposits in Azerbaijan, Agapa, Taymir Peninsula, Russia (Cenomanian), Sarthe, France (Cenomanian), Timmerdyakh, Yakutia, Russia (Cenomanian-Turonian), Eastern Taymir, Russia (Albian to Cenomanian) (Martinez-Delclos et al. 2004), Alem Ketema, Ethiopia (Cenomanian) (Schmidt et al. 2010), Burmese amber (Early Cenomanian) (Ross et al. 2010), Charentese amber, France (Albian-Early Cenomanian) (Perrichot et al. 2007).

\section{Nuclear Magnetic Resonance Spectroscopy Experiments and Results}

Two samples were selected from the Grayson deposition, one transparent reddish orange (sample number 1749 in the Northwestern/Trinity catalogue) and the other a mixture of transparent light reddish orange and opaque brown (1750). A third sample was selected that was opaque black to represent the matrix from which the amber materials were extracted (1751). For comparison, spectra were recorded from samples from other parts of the United States. Sample 846 was from Sayreville, Middlesex County, New Jersey, Parlin Pit, Raritan Formation, Late Cretaceous/Cenomanian (93.5-99.6 Ma), provided by the New Jersey State Museum (representing several previously studied samples from New Jersey sources). Sample 1030 was provided by the National Museum of Natural History, Department of Paleobiology (their sample 1030), from King County, Washington, translucent yellow.

Figure 8 presents the solid-state 13C spectrum of sample 1749 with full decoupling. The spectrum of sample 1750 was substantially the same, but that of sample 1751 was very weak and showed only resonances from carbons found in coal-like materials, in contrast to amber. Figure 9 presents the onedimensional, solution-state $1 \mathrm{H}$ spectrum of sample 1749 in $\mathrm{CDCl} 3$. The $1 \mathrm{H}$ spectrum of sample 1750 was essentially identical, whereas sample 1751 was insufficiently soluble to provide a spectrum (a typical result for coal). Figure 10 and 11 provide analogous $13 \mathrm{C}$ and $1 \mathrm{H}$ spectra, respectively, for sample 846 , and Figures 12 and 13 for sample 1030.

Figure 8 represents the spectrum of a typical Group A (mass spectral Class 1b) amber. The observed resonances may be divided into four groupings. The dominant region between $\delta 10$ and 60 derives from entirely saturated carbons (those attached to other carbons and without double bonds). The symbol $\delta$ is the traditional unit of NMR chemical shifts, expressed in parts per million of the magnetic field, with zero at the resonance position of the standard, tetramethylsilane $[(\mathrm{CH} 3) 4 \mathrm{Si}]$. The intensities and the positions of the peaks are characteristic of Group A. It bears a close resemblance, for example, to the 
spectrum of walchowite, a type of amber from Czechia (Figure 4, Lambert et al. 2008). This same reference illustrates the contrasting spectra of Groups A, C, and $\mathrm{D}$ ambers. The region of small peaks from $\delta 70$ to 100 contains resonances from saturated carbons attached to electron-withdrawing atoms and groups, particularly oxygen. The important unsaturated region from $\delta 110$ to 150 contains resonances from doubly bonded carbons $(>C==C<$. In the Grayson spectra, these resonances are more pronounced than those of the Czech sample. The spectrum lacks peaks at $\delta 110$ and 150 from exomethylene groups $(>\mathrm{C}==\mathrm{CH} 2$ ) usually present in Baltic amber (Group C) and Latin American and African ambers (Group D). Finally, the region from $\delta 160$ to 210 contains resonances from carbonyl carbons $(>\mathrm{C}==\mathrm{O})$.

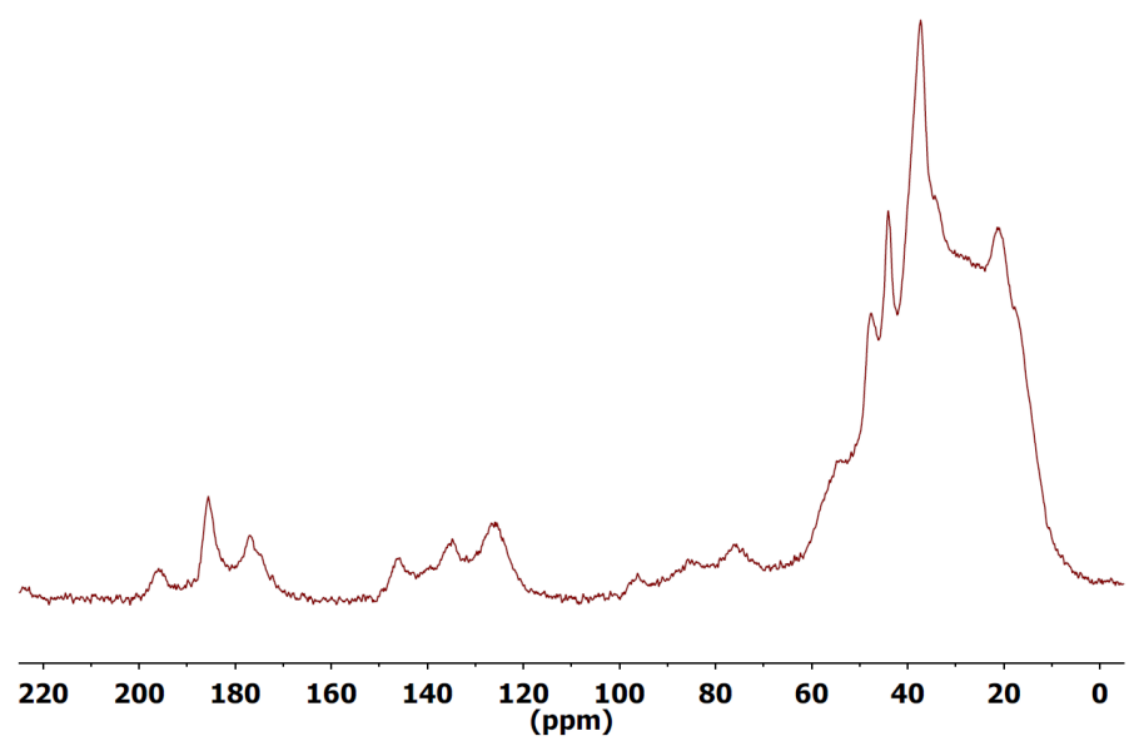

Figure 8. The solid state ${ }^{13} \mathrm{C}$ spectrum of amber from Grayson County, Texas, (sample 1749) with full decoupling.

The ${ }^{1} \mathrm{H}$ spectrum of sample 1749 (Figure 9) also is typical of Group A ambers, as seen from comparison spectra (Figure 1, Lambert et al. 2012). There are four important regions in ${ }^{1} \mathrm{H}$ spectra. Again, the saturated region, $\delta$ 0.6-2.0 is dominant, and the electron-withdrawing region from $\delta 2.0$ to 3.0 contains small but important peaks. For this sample, the double bond region, $\delta 4.0-6.0$, is nearly empty. The ${ }^{1} \mathrm{H}$ spectrum has a unique region $(\delta 6.5-8.0)$ in which aromatic peaks (those from protons attached to benzene rings) resonate. $\mathrm{In}^{13} \mathrm{C}$ spectra, double bond (alkene) and aromatic peaks coincide in the unsaturated region, but these two types of protons are well differentiated in ${ }^{1} \mathrm{H}$ spectra. In the comparison spectrum of an amber from Washington (Figure 1, Lambert et al. 
2008), the aromatic region is identical to that in Figure 9. The peak at $\delta 7.3$ is from the solvent $\mathrm{CHCl}_{3}$.

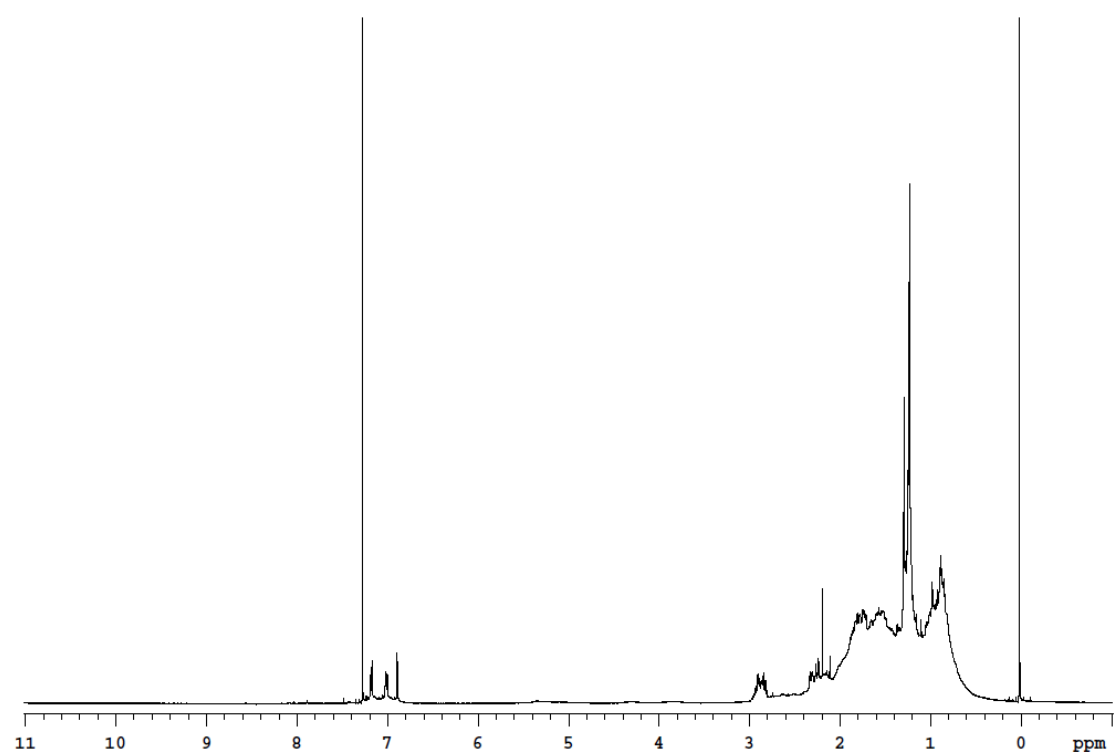

Figure 9. The ${ }^{1} \mathrm{H}$ spectrum of amber from Grayson County, Texas, (sample 1749) in $\mathrm{CDCl}_{3}$.

Figure 10 contains the ${ }^{13} \mathrm{C}$ spectrum of the New Jersey sample, which is nearly identical to those from the Grayson samples. The dominant and diagnostic saturated region is normal for a Group A amber. In this sample, the unsaturated and carbonyl resonances are weaker than those of the Grayson sample, generally indicative of a more matured sample. The ${ }^{1} \mathrm{H}$ spectrum of the New Jersey sample also is characteristic of Group A ambers (Figure 11). The similarities in fact are remarkable: two peaks of unequal intensities at $\delta 0.8$ and 1.0, a sharp peak at $\delta 1.3$, two peaks at $\delta 1.6$ and 1.8, a group of peaks at $\delta 2.1-2.4$, another group at $\delta 2.9$, no double bond peaks, and the same three aromatic peaks $\delta 6.9,7.0$, and 7.2. There are minor differences, not unexpected: a small multiplet at $\delta 1.9$ present for New Jersey but absent for Grayson, a small, sharp peak at $\delta 7.1$ for New Jersey but not for Grayson.

The ${ }^{13} \mathrm{C}$ spectrum of the Washington sample (Figure 12) provides a third example of Group A amber, like those of Figures 8 and 10. The ${ }^{1} \mathrm{H}$ spectrum (Figure 13) also is characteristic of Group A, although in a more intense presentation. Additional peaks are present at $\delta 3.4$ and 3.8 in the electronwithdrawing region, but otherwise the spectrum is closely like those in Figures 9 and 11 , in the aromatic region. 


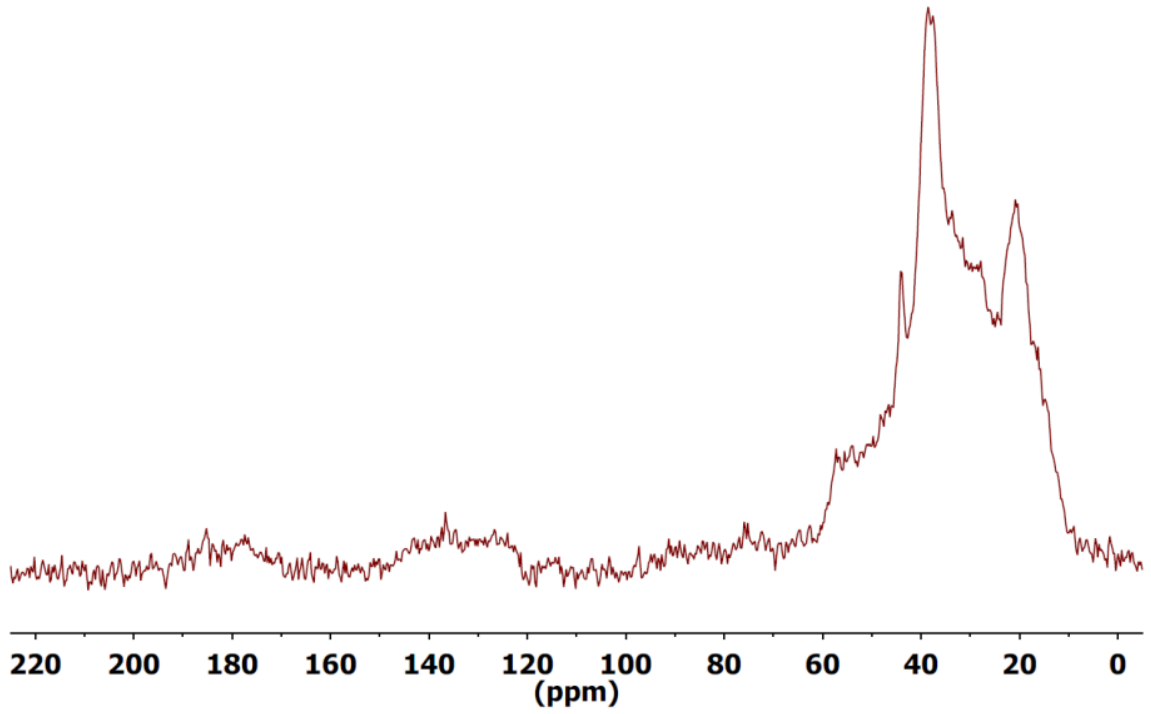

Figure 10. The solid state ${ }^{13} \mathrm{C}$ spectrum of amber from Middlesex County, New Jersey, (sample 846) with full decoupling.

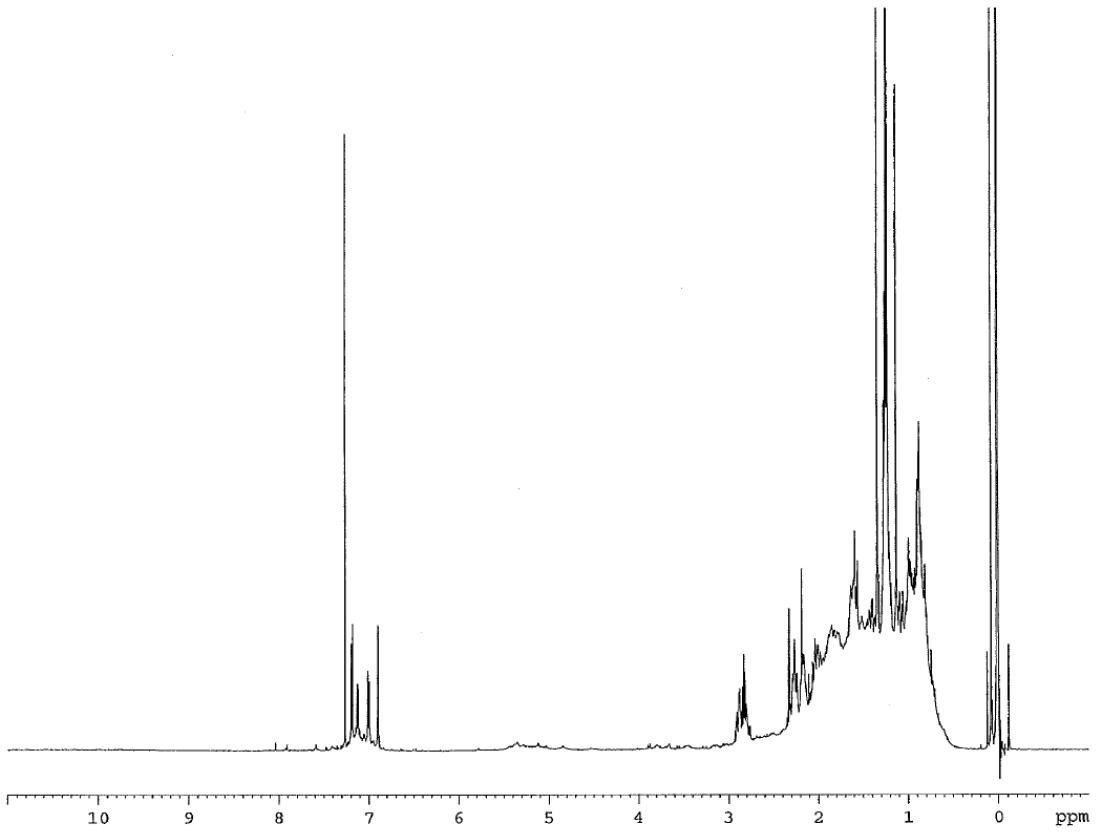

Figure 11. The ${ }^{1} \mathrm{H}$ spectrum of amber from Sayreville, Middlesex County, New Jersey (sample 846) in $\mathrm{CDCl}_{3}$. 


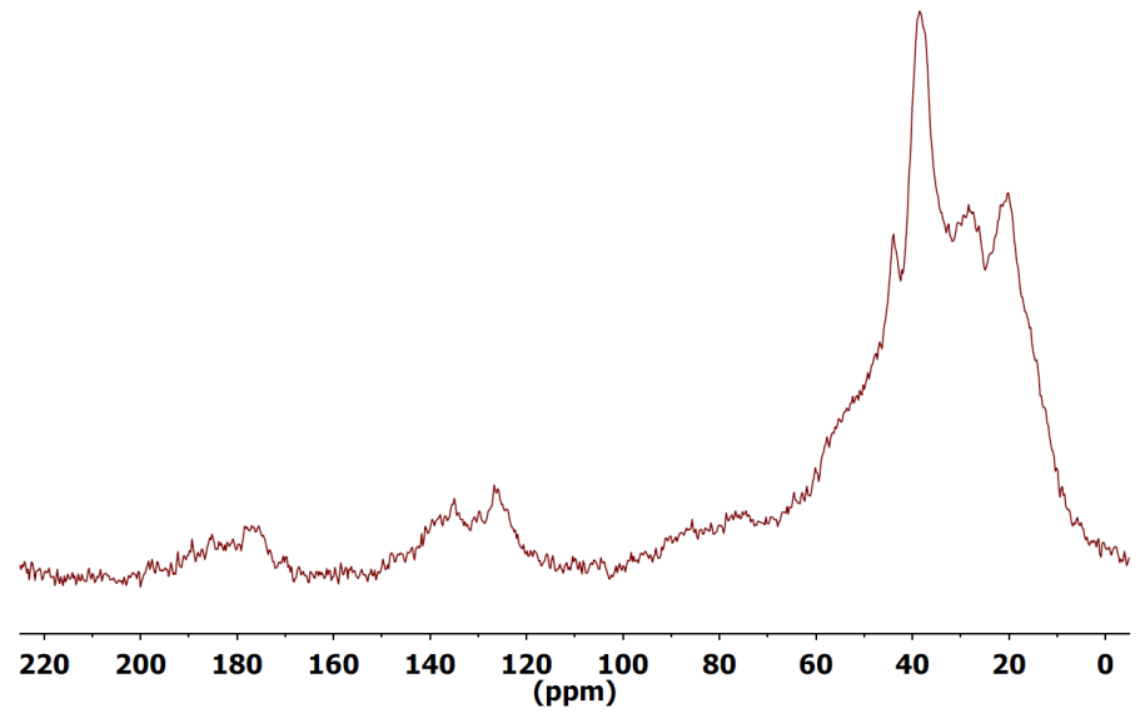

Figure 12. The solid state ${ }^{13} \mathrm{C}$ spectrum of amber from King County, Washington, (sample 1030) with full decoupling.

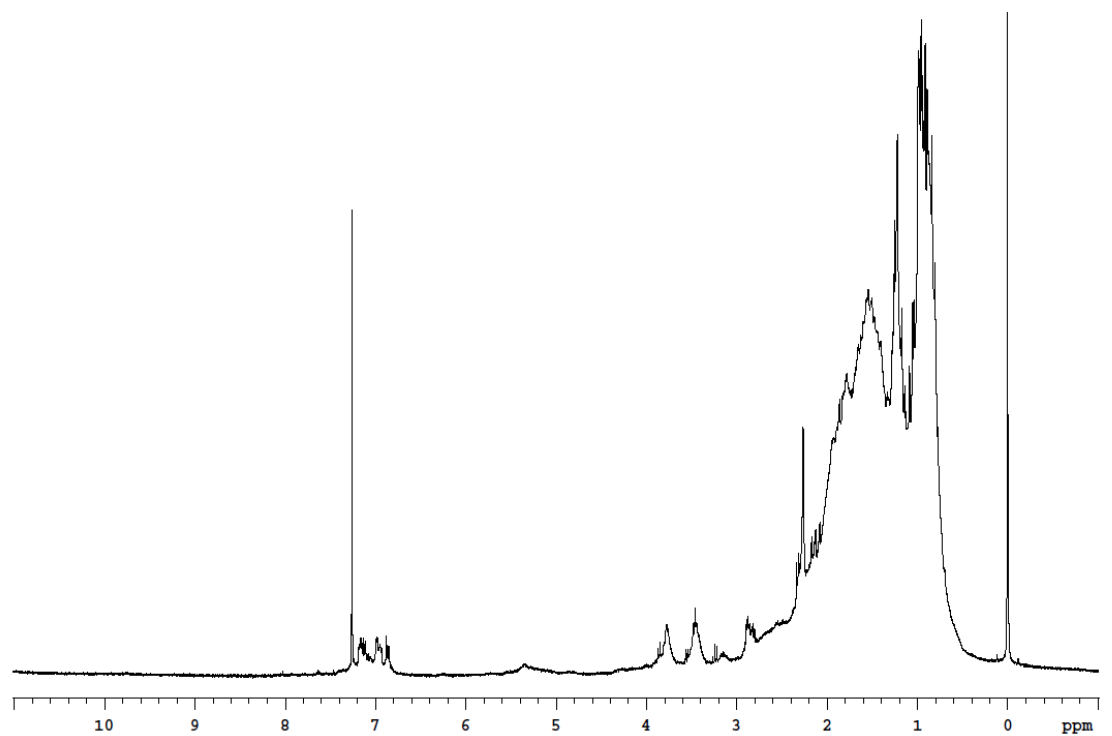

Figure 13. The ${ }^{1} \mathrm{H}$ spectrum of amber from Sayreville, King County, Washington, (sample 1030) in $\mathrm{CDCl}_{3}$. 


\section{Infrared Spectroscopy Experiments and Results}

FTIR spectra were recorded for two Grayson samples, which ranged from yellow to light brown. The FTIR spectra of the larger Texas sample are shown in Figures 14 and 15, along with two spectra for comparison (authentic Baltic and Nebraska ambers). Spectra of the two Texas samples were similar, indicating a close correspondence in chemical composition. In general, all three spectra show peaks for organic groups typically expected in fossil resins (reported here in $\mathrm{cm}^{-1}$ ): $\mathrm{OH}$ (3439), vinyl region (small peaks at 3062 and 884$)$, aliphatic $(\sim 2900,1459$, and 1382), and esters $(\sim 1735$, 1100-1300). There is no resemblance between the Grayson and Baltic samples, as expected, but the Grayson and Nebraska samples are very similar. The vinyl region (small peaks at $\sim 310$ and the peak at $888 \mathrm{~cm}^{-1}$ typically are associated with exocyclic double bonds on cyclohexane rings (exomethylene groups). With more polymerization in ambers, this peak decreases and thus is smaller in older ambers. A qualitative comparison of the $888 \mathrm{~cm}^{-1}$ peak in Figure 15 seems to indicate that it is smaller (or less prominent) for the Grayson amber in comparison with the Baltic sample. The implication here is that the Grayson amber is older than the Baltic amber, consistent with the observed age of the Texas amber (96.5 to 97. $3 \mathrm{Ma}$ ).

A closer inspection of the Grayson and Nebraska ambers in Figure 15 also shows the presence of a small (but clearly discernible) shoulder peak at $1497 \mathrm{~cm}^{-1}$, which together with the $\sim 3100$ peaks (small as they are) suggest greater degree of aromatic character. This inference also is supported by GC/MS analysis discussed in the next section. The peak at $1497 \mathrm{~cm}^{-1}$ provides another point of similarity between the Grayson and Nebraska ambers, in addition to the correspondence in the region 1100$1300 \mathrm{~cm}^{-1}$ that corresponds to $\mathrm{C}-\mathrm{O}$ groups.

The Texas sample also was studied by GC/MS for a closer evaluation of its chemical composition (Table 2). The GC scan shows few peaks between 4 and 20 min (a few monoterpenes and sesquiterpenes), as most of the peaks are between 22-30 min and correspond to diterpenes. No triterpenes were detected. Methyl succinate and its derivatives were not detected, a compound only consistent with Baltic amber. Based on the molecular structure of the diterpenes (Table 2) identified in the Grayson sample, most of them correspond to the abietane carbon skeleton and are consistent with the assignment as a Class $1 \mathrm{~b}$ amber. The major diterpene is methyl dehydroabietate, making up $\sim 80 \%$ of the organics that were extracted from the Texas amber. Caution should be exercised with such an observation, which depends highly on the extraction process necessary for the GC/MS experiment. The high concentration of methyl dehydroabietate is possibly the reason for the aromatic $1497 \mathrm{~cm}^{-1}$ peak observed in the FTIR spectra of the Grayson and Nebraska ambers. Overall, the Grayson amber shows smaller distribution of diterpenes and a higher percentage of methyl dehydroabietate than we previously have observed in diterpene based fossil resins. This interpretation should be viewed cautiously in terms of relating it to the bulk amber because the GC/MS analysis represents only the composition of the organic compounds that could be extracted with the organic solvent. 


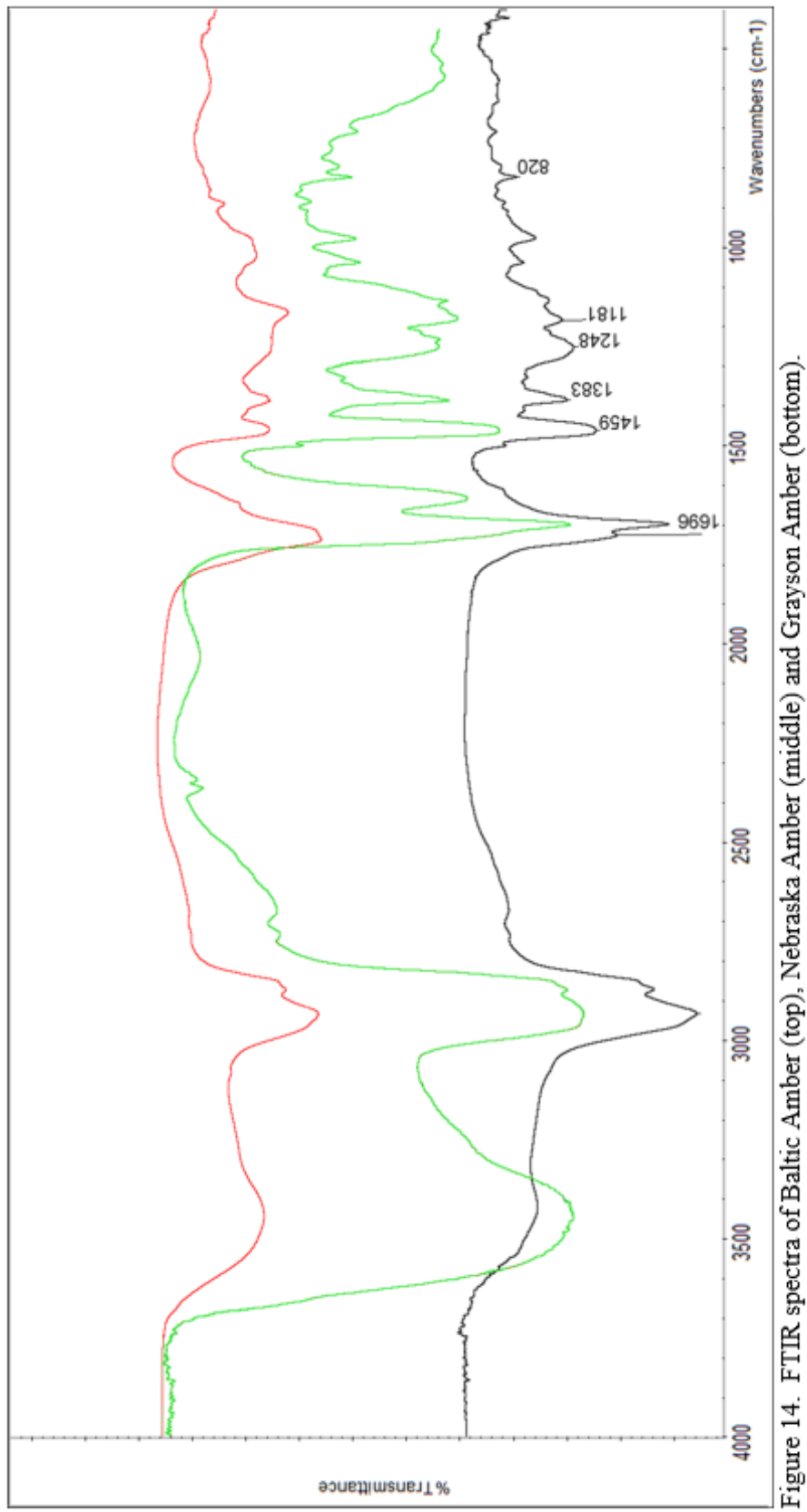




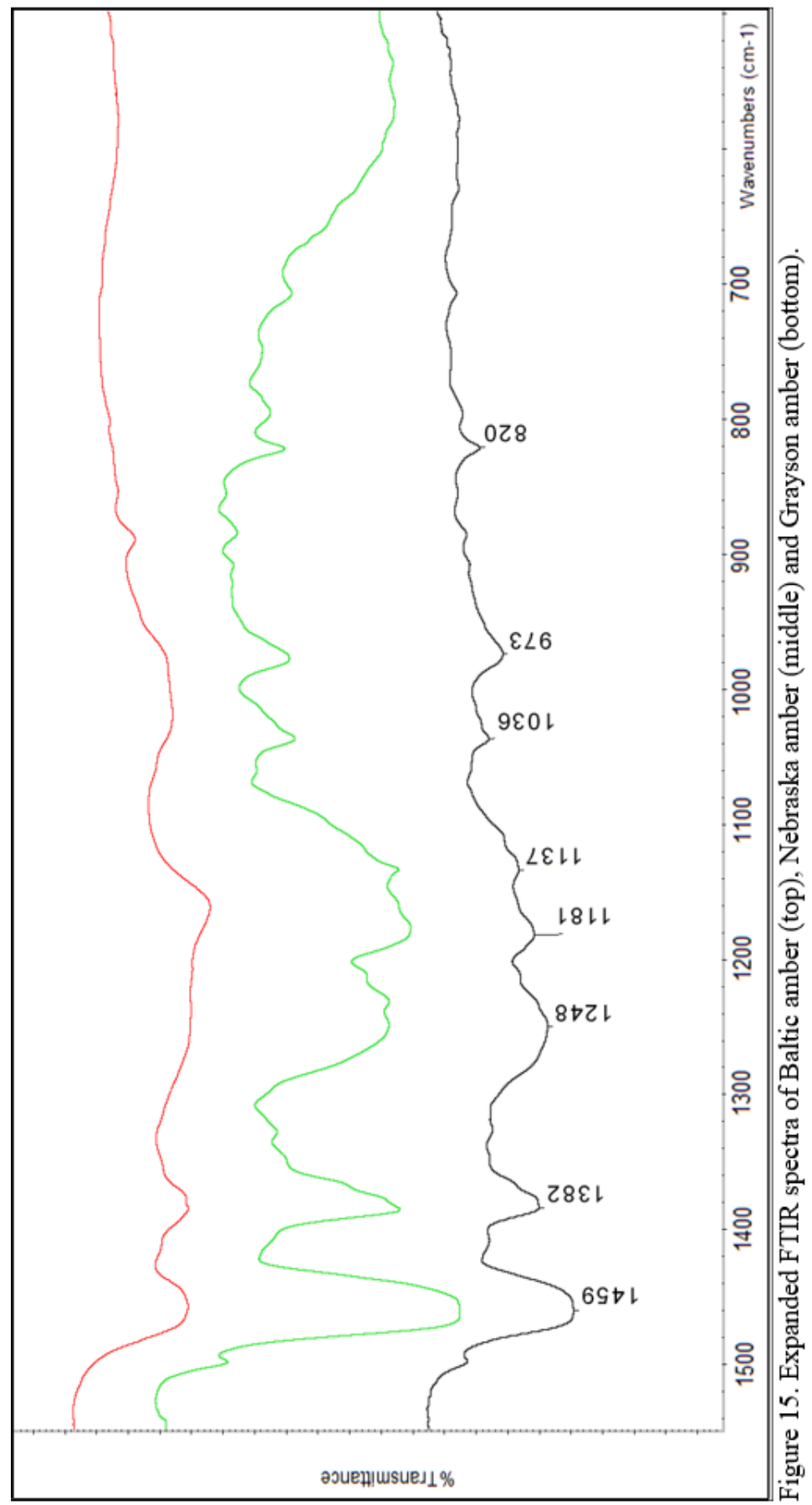


Table 2. Chemical composition of Grayson Amber by GC/MS analysis*.

\begin{tabular}{|c|c|c|c|c|c|}
\hline RT & $\mathbf{M}^{+}$ & $\mathbf{B P}$ & $\begin{array}{c}\mathrm{m} / \mathrm{z} \\
\text { (descending } \\
\text { abundance) }\end{array}$ & Compound & $\%$ \\
\hline 2.75 & 72 & 43 & 57 & butanal & $\operatorname{tr}$ \\
\hline 3.14 & 138 & 95 & $109,55,67,70$ & trimethyl norboranane & $\operatorname{tr}$ \\
\hline 3.26 & 138 & 95 & $109,55,67,69$ & isomer of RT 3.15 & $\operatorname{tr}$ \\
\hline 3.33 & & 97 & 96,55 & unknown, aliphatic & 0.04 \\
\hline 4.24 & 134 & 119 & 117,91 & Cymene & 0.04 \\
\hline 5.07 & 152 & 81 & 69,80 & Fenchone & 0.16 \\
\hline 6.16 & 152 & 95 & $\begin{array}{c}81,108,109,83, \\
55,67 \\
\end{array}$ & Camphor & 1.27 \\
\hline 12.56 & 194 & 109 & $\begin{array}{c}95,81,123,55 \\
110,82 \\
\end{array}$ & tetramethyl decalin & 0.08 \\
\hline 13.77 & 204 & 119 & 120 & dihydro-ar-curcumene? & 0.05 \\
\hline 13.88 & & 109 & 95,81 & $\begin{array}{c}\text { dimethyl } \\
\text { octahydronapthalene }\end{array}$ & $\operatorname{tr}$ \\
\hline 14.03 & & & & & 0.05 \\
\hline 14.40 & 174 & 159 & $\begin{array}{l}129,128,160 \\
144,115,131\end{array}$ & Ionene & 0.21 \\
\hline 15.19 & & 173 & & & $\operatorname{tr}$ \\
\hline 16.43 & 170 & 155 & & trimethyl naphthalene & $\operatorname{tr}$ \\
\hline 19.68 & 214 & 117 & 99 & Unknown & $\operatorname{tr}$ \\
\hline 20.21 & & 175 & $119,191,190$ & $\begin{array}{l}\text { octahydrotetramethyl- } \\
\text { napthalene }\end{array}$ & 0.07 \\
\hline 22.80 & & 134 & $92,133,91,69$ & Unknown & 0.07 \\
\hline 22.94 & 256 & 159 & $241,117,185$ & $\begin{array}{c}\text { dehydroabietin(18- } \\
\text { norabietatriene) }\end{array}$ & 0.16 \\
\hline 22.94 & & 159 & 134,92 & isomer of RT 22.80 & $\operatorname{tr}$ \\
\hline 24.61 & 256 & 159 & $\begin{array}{l}241,185,117 \\
128,129,242 \\
\end{array}$ & norabieta- $8,11,13$-triene & 2.3 \\
\hline 24.88 & & 73 & 215,60 & Unknown & 0.17 \\
\hline 24.95 & & 119 & 120 & Unknown & 0.09 \\
\hline 25.21 & 256 & 159 & $\begin{array}{l}241,185,143, \\
129,128,242\end{array}$ & isomer norabietatriene & 0.23 \\
\hline 25.67 & 242 & 227 & $\begin{array}{l}143,128,140, \\
228\end{array}$ & $\begin{array}{c}\text { Octahydrotetramethylphena } \\
\text { nthrene }\end{array}$ & 0.19 \\
\hline 26.47 & 272 & 197 & $\begin{array}{l}131,198,141 \\
129,128,257\end{array}$ & $\begin{array}{c}\text { methyl } \\
\text { deisopropyldehydroabietate }\end{array}$ & 1.12 \\
\hline 26.52 & 238 & 223 & $\begin{array}{c}181, \\
195,165,167,179\end{array}$ & $\begin{array}{l}\text { tetrahydroretene; } 7- \\
\text { isopropyl- methyl- } \\
\text { tetrahydrophenanthrene }\end{array}$ & $\operatorname{tr}$ \\
\hline
\end{tabular}




\begin{tabular}{|c|c|c|c|c|c|}
\hline 27.81 & 316 & 146 & 133 & isomer of RT 28.10 & 0.07 \\
\hline 28.10 & 316 & 146 & $\begin{array}{c}133,187,101 \\
92,91\end{array}$ & $\begin{array}{c}\text { methyl }(2 \beta)-9,10 \text { seco- } \\
\text { dehydro-abietate }\end{array}$ & 0.5 \\
\hline 28.44 & 316 & 146 & $\begin{array}{c}133,131,117,91, \\
109,284\end{array}$ & isomer of RT 28.10 & 2.66 \\
\hline 30.07 & 318 & 121 & $\begin{array}{c}215,107,81 \\
136,91 \\
\end{array}$ & methyl dihydroabietate & 0.07 \\
\hline 30.22 & 318 & 243 & $\begin{array}{l}303,91,187 \\
105,107,259\end{array}$ & methyl 8-abieten-18-oate & 0.33 \\
\hline 30.51 & 318 & 243 & $\begin{array}{l}163,91,303 \\
259,105,187 \\
\end{array}$ & isomer of 30.22 & 8.9 \\
\hline 30.64 & 314 & 239 & $\begin{array}{c}240,299,141 \\
128,129,155\end{array}$ & methyl dehydroabietate & 80.5 \\
\hline 31.00 & 314 & 227 & $\begin{array}{c}239,107,91, \\
243\end{array}$ & $\begin{array}{l}\text { methyl dehydroabietate } \\
\text { related }\end{array}$ & 0.12 \\
\hline 33.31 & 330 & 255 & 237,315 & $\begin{array}{l}\text { methyl hydroxyl } \\
\text { dehydroabietate }\end{array}$ & $\operatorname{tr}$ \\
\hline 33.94 & 328 & 253 & 187,254 & $\begin{array}{c}\text { methyl 7- } \\
\text { oxodehydroabietate }\end{array}$ & $\operatorname{tr}$ \\
\hline
\end{tabular}

* RT (retention time), MI (molecular ion), BP (base peak), m/z (mass per charge), and tr (traces or amounts too small to be measured).

\section{Discussion}

Ambers are not fossilized resins in the strict sense of the word. Ambers appear to be little changed from the time they were exuded by the plant be it angiosperm or gymnosperm as it is now known (Santiago-Blay and Lambert 2007). Chemically, resins are made from complex arrangements of the fivecarbon molecule called isoprene (2-methyl-1,3-butadiene or $\mathrm{C}_{5} \mathrm{H}_{8}$ ), which polymerizes to form di- and triterpenes. The resins become amber by the primary mechanism of cross-linking and polymerization of the isoprene units. The process takes place under elevated temperature and pressure over long geologic time (Santiago-Blay and Lambert 2007). The process is nonlinear and still is not well understood. It is part of a continuum: resin-copal-amber. Resin plant production is an ancient process occurring (although in minute amounts) from the Carboniferous to the vast Eocene amber deposits of the Baltic region to the present. Examination of the solid-state ${ }^{13} \mathrm{C}$ and solution ${ }^{1} \mathrm{H}$ NMR spectra of fossilized resins (ambers) has generated five groupings of materials based on spectral characteristics (Lambert et al. 2008). The worldwide Group A is associated primarily with the botanical family of the Araucariaceae. The worldwide Group B is associated with the Dipterocarpaceae. Baltic amber or succinate (Group C) is related to Group A but with a disputed conifer source. Amber from Latin America, the Caribbean, and Africa is associated with the Fabaceae, the genus Hymenaea in particular. The minor Group E contains the rare fossil polystyrene. The Texas amber belongs to Group A based on its ${ }^{13} \mathrm{C}$ and ${ }^{1} \mathrm{H}$ NMR spectra or to the equivalent Class $1 \mathrm{~b}$ (based on its MS spectra). 
The examination of the amber pieces under the stereoscope is still ongoing; higher magnification and state of the art microscopy techniques will be needed. No definitive zooinclusions have been found yet. Many amber clasts present phytoinclusions, but they appear for the most part detrital and not suitable for taxonomical classification. Inorganic inclusions are abundant: microscopic bubbles of different size and shape as well as abundant acicular (needle-like) sulfate crystals (probably jarosite or selenite) have been observed. The Texas amber deposit is considered, with caution, a primary deposit based on its palynomorph content and the overall sedimentological presentation of the deposit. The possibility of reworking in fluvial systems is always high. However, the low diversity palynomorph assemblage suggests a localized source area (Zippi 2016). The age of the sediments where the amber is contained is Early Cenomanian based on stratigraphy and secondarily based on palynological data of the outcrop. The discovery of amber in the Upper Cretaceous of Texas in sufficient amount to carry on extensive multidisciplinary research, clasts size and aesthetic attributes is a significant paleontological find not only for Texas but for the global record of amber. The Texas find is an important contribution to the study of ambers on Earth.

\section{Future Work}

Microscopy of higher magnification is needed to ascertain the presence (or lack of) of zooinclusions and to aid in the determination of taxonomical affinity of the phytoinclusions present in the Texas amber. It is very likely that microinclusions (i.e., mites, bacteria, protozoans, fungi, spores, pollen) will be found. If successful, this will open new opportunities of research in middle Cretaceous paleoentomology and paleomicrobiology. The definitive taxonomic affinity of the Texas amber producing conifer(s) is still unresolved. Further chemical analysis will be needed. Optical characterization of this amber is planned for the near future. Rheological studies are in progress. The ongoing fieldwork will assure the effective recovery of this important fossil resin for future studies.

\section{Acknowledgments}

The authors thank the Welch Foundation (Departmental Grant No. W-0031) for financial support of this work, Rodrigo Pellegrini of the New Jersey State Museum for providing sample 846 from the Ralph Johnson collection (their sample number GP 17568 and NH 1994.60), the Geologisches Staatsinstitut, Hamburg, West Germany, for providing the Baltic sample and the American Museum of Natural History for providing the Nebraska sample, NE-5 site, ARL IR6169). The following individuals are greatly appreciated for their assistance in this project: A. Brown, Y. Wu, C. L. Johnson, H. Friedman, R. Denne, G. Mustoe, J. A. Santiago-Blay, N. Vavra, A. Bugarin, and C. Hotton. We would also like to thank five anonymous reviewers. Their comments and insights greatly improved the original manuscript. This work is dedicated to Bill and Wanda Lowe of Granbury, Texas, USA. 


\section{Literature Cited}

Anderson, K. B. 2006. Investigations of C-ring aromatic diterpenoids in Raritan amber by pyrolysisGC-matrix isolation FTIR-MS. Geochemical Transactions. The Nature and Fate of Natural Resins in the Ggeosphere XII. 7:2.

Dodge, C. F. 1952. Stratigraphy of the Woodbine Formation in the Arlington area, Tarrant County, Texas. Field and Laboratory 20(2):66-77.

Donovan A.D., Gardner R.D., Pramudito A., Staerker, S. Wehner, M. Corbett, M. Lundquist, J. J. Romero A., Henry L., Rotzien J. and K.S. Bohling. 2015. Chronostratigraphic relationships of the Woodbine and Eagle Ford Groups across Texas. Gulf Coast Association of Geological Societies Journal 4:67-87.

Denne, R. A, J. A. Breyer, A. D. Callender, R. E. Hinote, M. Kariminia, T. Kosanke, Z. Kita, J. A. Lees, H. Rowe, J. M. Spaw, and N. Tur. 2016. Biostratigraphic and geochemical constraints on the stratigraphy and depositional environments of the Eagle Ford and Woodbine Groups of Texas. In, Breyer, J. A. (Editor). The Eagle Ford Shale: A renaissance in U.S. oil production. American Association of Petroleum Geologists (AAPG) Memoir 110. pp. 1-86. https://doi.org/10.1306/13541957M1103660

Drehobl, M. B. 2013. Paleoecological Reconstructtion of Mid- Cretaceous plant communities from the Dakota Formation of Iowa, USA. Master of Science degree in Geoscience in the Graduate College of The University of Iowa University of Iowa. $125 \mathrm{pp}$. http://ir.uiowa.edu/etd/2481 , http://ir.uiowa.edu/cgi/viewcontent.cgi?article $=4609 \&$ context $=$ etd

Friedman, V., T. Nguyen, and J. B. Lambert. 2017. Late Cretaceous Amber in Texas: A preliminary study. Botanical Society of America, Paleobotany Section. Fort Worth, Texas, USA. Poster PPB001

Grabowska, J. 1993. Polish Amber. Interpress Publisher. Warsaw, Poland. 89 pp.

Grimaldi, D. (Editor) 2000. A remarkable deposit of fossiliferous amber from the Upper Cretaceous (Turonian) of New Jersey. Studies on fossil in amber. Backhuys Publishers. Leiden, The Netherlands. 76 pp.

Hill, R. T. 1901. Geography and geology of the Black and Grand Prairie, Texas: U.S. Geological Survey. 21st Annual Report 1899-1990. 666 pp.

Hollick, A. 1905. The occurrence and origin of amber in the Eastern United States. The American Naturalist 39(459):137-145. https://doi.org/10.1086/278500

Kennedy, W. J. and W. A. Cobban. 1990. Cenomanian ammonite faunas from the Woodbine Formation and lower part of the Eagle Ford Group, Texas. Paleontology 33(1)75-154.

Lambert, J. B., J. A. Santiago-Blay, and K. B. Anderson. 2008. Chemical signatures of fossilized resins and recent plant exudates. Angewandte Chemie (International Edition English) 47:96089616. Angewandte Chemie 120:9750-9760. https://doi.org/10.1002/ange.200705973

Lambert, J. B., E. W. Donnelly, E. A., Heckenbach, C. L. Johnson M. A. Kozminski, Y. Wu, and J. A. Santiago-Blay, 2013. Molecular classification of the natural exudates of the rosids, Phytochemistry 94:171-183. https://doi.org/10.1016/j.phytochem.2013.06.013

Lambert, J. B., C. Y. Tsai, M. C. Shah, A. E. Hurtley, and J. A. Santiago-Blay, 2012. Distinguishing amber classes by Proton Magnetic Resonance Spectroscopy. Archaeometry 54:332-348. https://doi.org/10.1111/j.1475-4754.2011.00625.x

Langenheim J. H. 2003. Plant Resins: Chemistry, Evolution, Ecology, Ethnobiology. Timber Press, Inc. Portland, Oregon, USA. 586 pp.

Langenheim R. L., Jr., J. D. Buddhue, and G. Jelinek, 1965. Age and occurrence of the fossil resins bacalite, kansasite, and jelinite. Journal of Paleontology 39(2): 283-287.

Martínez-Delclos, X, D. E. G. Briggs, and E. Peñalver, 2004. Taphonomy of insects in carbonates and amber. Palaeogeography, Palaeoclimatology, Palaeoecology 203:19-64. https://doi.org/10.1016/S0031-0182(03)00643-6

Oliver, W. B. 1971. Depositional systems in the Woodbine Formation (Upper Cretaceous), northeast Texas: The University of Texas at Austin, Bureau of Economic Geology, Report of Investigations No. 73.28 pp. https://doi.org/10.23867/RI0073D 
Opella, S. J. and M. H. Frey. 1979. Selection of nonprotonated carbon resonances in solid-state nuclear magnetic resonance. Journal of the American Chemical Society 101:5854-5856. https://doi.org/10.1021/ja00513a079

Perrichot V., D. Neraudeau, A. Nel, G. de Ploeg. 2007. A reassessment of the Cretaceous amber deposits from France and their paleontological significance. African Invertebrates 48:213-227.

Reinicke, R. 1990. Bernstein-Gold des Meeres. Hinstorff Verlag GmbH. Rostock, Germany. 80 pp.

Ross A., C. Mellish, P. York, and B. Crighton. 2010. Burmese amber. pp. 208-235. In, Penney, D. (Editor). Biodiversity of Fossils in Amber from the Major World Deposits. Siri Scientific Press. Manchester, England, UK. 304 pp.

Santiago-Blay, J. and J. B. Lambert, 2007. Amber's botanical origins revealed. American Scientist 95:150-157. https://doi.org/10.1511/2007.64.1020

Schmidt A. R., V. Perrichot, M. Svojtka, K. B. Anderson. K. H. Belete, R. Bussert, H. Dörfelt, S. Jancke, B. Mohr, E. Mohrmann, P. C. Nascimbene, A. Nel, P. Nel, E. Ragazzi, G. Roghi, E. E. Saupe, K. Schmidt, H. Schneider, P. A. Selden, and N. Vávra. 2010. Cretaceous African life captured in amber. Proceedings of the National Academy of Sciences of the United States of America.107:7329-34. https://doi.org/10.1073/pnas.1000948107

Scott, A. C. 2010. Charcoal recognition, taphonomy and uses in paleoenvironmental analysis. Palaeogeography,
https://doi.org/10.1016/j.palaeo.2009.12.012

Palaecoecology

291:11-39.

Stephenson, L. W. 1952. Larger invertebrate fossils of the Woodbine Formation (Cenomanian) of Texas. USGS Professional Paper 242. 226 pp. +59 plates, and maps.

Troost, G. 1821. Description of a variety of amber and fossil substances supposed to be the nest of an insect discovered at Cape Sable, Magothy River, Anne Arundel County, Maryland, USA. American Journal of Science III(1):8-15.

Wilkins, K. 1998. Hydrologic report of the Woodbine, Marietta, and Texoma minor bedrock groundwater basins and the Haworth Terrace and Little River alluvial and terrace minor groundwater basins. Oklahoma Water Resources Board. Planning \& Management Division. Technical Report 99-2. 34 pp.

Zippi, P. A. 2016. Palynology of one Woodbine Formation outcrop sample from north central Texas. Biostratigraphy.com, LLC. Report \# 1123. http://biostratigraphy.com/ 